\title{
The Use of Audio-Visual Materials in the Teaching and Learning Processes in Colleges of Education in Benue State-Nigeria
}

\author{
Doosuur Ashaver ${ }^{1}$, Sandra Mwuese Igyuve ${ }^{2}$ \\ Benue State University, Makurdi-Nigeria
}

\begin{abstract}
The work is the use of audio-visual resources in Colleges of Education in Benue State: with specific reference to the College of Education, Katsina-Ala. The study was based on achieving the following purposes: To evaluate how the library meets the needs of the teachers in supply of audio-visual materials; the types and quality of audio-visual materials available in the college, their frequencies of use and inhibitions and finally what steps the librarian has taken in promoting or creating an awareness of the available audio-visual resources in the library. Two sets of questionnaires were administered to lecturers and staff in order to elucidate the needed information. The researcher also went to the college to observe and also to administer the questionnaire. Through the questionnaire and observation made by the researcher, data were collected, organized and analysed using non-parametric statistical techniques like percentages and frequencies; mean was also used in research question three for easy analysis and discussion because of the number of the items involved. It was finally discovered that:The College collection of audio-visual materials is fairly adequate. The lecturers in the college rarely use audio-visual resources in teaching. The chalkboard is the only audio-visual material frequently used by the lecturers. Non-availability, lack of supporting infrastructures and human factors are hindrances to the use of audio-visual aids in the college. There are numerous benefits that students derive from the use of audio-visual aids. The awareness of available audio-visual resources created by the librarian is not impressive.
\end{abstract}

\section{Background Of The Study}

\section{Introduction}

Webster's Encyclopeadia Unabridged Dictionary of the English Language, defines Audio-Visual a Aids as "training or educational materials directed at both the senses of hearing and the sense of sight, films, recordings, photographs, etc used in classroom instructions, library collections or the likes".

The term has also been defined by (Dike, 1993) as; those materials which do not depend solely upon reading to convey meaning. They may present information through the sense of hearing as in audio resources, sight, as in visual resources or through a combination of senses. Indeed, the variety of such resources is a striking characteristic.

According to (Anzaku, 2011) "the term audio-visual materials is commonly used to refer to those instructional materials that may be used to convey meaning without complete dependence upon verbal symbols or language". Thus according to the above definition, a text book or a reference material does not fall within this grouping of instructional materials but an illustration in a book does. Some audio-visual components are in the nature of process and experience, for example, dramatizing an event or a procedure or making diorama. Some of the audio-visual materials like the motion pictures require the use of equipment to release their latent value. Some do not need equipment at all like an exhibit or a study print. T his term designates in common usage both material things as well as processes such as field trips.

Anzaku further stated that audio-visual materials include materials and equipment alike, that materials are considered to be system, or body of content of potential value when put to work, while equipment or instructions, often referred to as hardware, components, are the means of presenting such content.

The importance of audio-visual materials in the teaching and learning processes cannot be over emphasized. Below are some of the roles of audio-visual materials.

Basing learning in sense experience, Extending experience, Encouraging participation, Stimulating interest ,Individualizes instructions, Serves as a source of information, Making leaning permanent,1) Basing learning in sense experience: stressing the importance of audio-visual materials, ( Ngozi,B.O. Samuel,A.O.andIsaac, O.A., 2012) unanimously agreed that audio-visual materials are very important and useful in education because, the normal learner in so far as the functions of his preceptor mechanisms are concerned, gains understanding in terms of multiple impression recorded through the eye, ear, touch and other series. This is to say that audio-visual materials are the equipment through which that function can occur, that is does not occur in isolation, rather through a balance pattern from any preceptor mechanism that are stimulated by external occurrences. 
(Eze,E.U. 2013) also states that the human being learns more easily and faster by audio-visual processes than by verbal explanations alone. His ability to arrive at abstract concept through perceptual experience is however a phenomenon not clearly explained and perhaps not explicable.

Furthermore, (Oketunji, 2000) stressed that audio-visual materials when effectively used have these advantages. They lessen major weakness of verbalism, humanize and vitalize subject matter, provide interesting approach to new topics and give initial correct impressions, economic time in learning, supply concrete materials needed, stimulate the initiative of the pupils.

Swank,R.C (2011). stressing the effectiveness of visual materials in leaning, estimated that about $40 \%$ of our concepts are based upon visual experience, $25 \%$ upon auditory, $17 \%$ on tactile, $15 \%$ upon miscellaous organic sensation and 3\% upon taste smell. With the above assertion, it becomes clearer why audio-visual materials are important in the teaching and learning processes. This is because, they bring the different senses contributions together to get $100 \%$ clarity.

\section{Extending Experience:}

(Gopal V. P. 2010) stressed that audio-visual materials help the teacher to overcome physical difficulties of presenting subject matter. That is to say, with audio-visual materials, the barrier of communication and distance is broken. The culture and climatic conditions of other countries can be brought into the classroom with the aid of slides, films, filmstrips and projectors. This is important because, according to Dike (1993) "once the phenomenon is visualized, the picture and knowledge becomes very clear and permanent". Agreeing to this assertion, a $20^{\text {th }}$ century Chinese philosopher stated that "one picture is worth a thousand words".

\section{Encouraging Participation}

(Natoli, C. 2011) once again added that "audio-visual materials are rich opportunities for students to develop communication skill while actively engaged in solving meaningful problems". In other words, students certainly like it more and learn better if they are engaged in important and appealing activities. For example, involving students in bulletin board display will enhance their choice of colour and aid their understanding of the concept in question or when they join the teacher in dramatization of an event or a process.

\section{Stimulating Interest}

According to (Katherine M. 2009) "learning takes place effectively when the teacher sets out to provide learning situation in which a child will learn because of his natural reactions of the provided materials". During the process of learning, the teacher has to provide the learning situation to satisfy the natural reaction of the learner and this is through the use of instructional aids. The attention of the learner is caught and his interest is also won and he is ready to learn.

Fawcett Hills (1994) also contributing on the role of audio-visual materials in stimulating interest stated that "A friendly, accepting group climate is important in any learning situations, especially those materials that require students to reveal their ignorance and confront their fellow students". When there is a climate of acceptance for learning, then learning is stimulated.

\section{Individualise Instruction}

Lestage A. (1959) stressed that audio-visual materials provide a means of individualizing instruction. This he said is possible through programmed learning and tapes which enable the learner to learn at his pace and also to work on his own. Moreover, according to Dike (1993) the machine frees the teacher to work with individual students, since he or she is not now required to carry out routine drills. Production of resources by students is another way of individualizing instruction.

\section{Serves as a source of information}

According to Peterson, "the child is to think, but he must have the information to with". This audiovisual resources serves, because, the information can be got from the good use of perceptual instructional materials especially those provided from our locality. When they are used in the class, their familiarity gives a back-ground for understanding the information.

(Mcnaught, A.2007) also observed that audio-visual materials are very useful teaching and instructional as well as promotional aids. He further stressed that where consistency of presentation is desirable, audio-visual materials are useful. They provides experiences not easily secured in other ways and hence contribute to the depth and variety of learning. 


\section{Making learning permanent}

Audio-visual resources can play a major role of making learning permanent, (Gopal V. P. 2010) stressed that "audio-visual methods do seem to facilitate the acquisition, the retention and the recall of lessons learned, because, they seem to evoke the maximum response of the whole organism to the situations in which learning is done. And perceptual materials readily associate themselves with the unique experiential background of each individual. (Natoli, C. (2011) stressed that audio-visual materials are important in the teaching and learning processes because "Having seen something, most people remember, for whatever that thing was, it conjures up an image at a mere mention and can be talked about freely.

Dike (1993) also explained that students forget because of lack of interest and opportunities to use the knowledge they have gained later on. Audio-visual resources can therefore contribute to the clarity of information presented by allowing students to visualize what is learned. Thus the saying:

What I hear, I forget

What I see, I remember

What I do, I know

\section{Statement Of Problem}

The study is motivated by the fact that students do not retain for long or understand what they are taught without audio-visual aids. Such learning does not encourage participation and lacks interest or stimulation. It is not based in sense experience nor does it extend their experience. Above all, such learning cannot be permanent. Yet, there is also evidence of low utilization and non availability of audio-visual materials in schools. The study will therefore investigate materials in colleges of education in Benue state, the training institution for future teachers. So that note will be taken of the hindrances and work towards promoting the use of audio-visual materials.

\section{Purpose Of The Study}

1. The purpose of this study is to discover and document the use of audio-visual aids in teaching and learning processes in the Colleges of Education in Benue state with particular reference to the college of education Katsina-Ala.

2. It will also evaluate how the library meets the needs of the teachers in supply of audio-visual materials.

3. The study will also bring out the types and quantity of audio-visual material there are in the college library, the inhibitions to their use and the frequency of their use by the lecturers.

4. It will investigate what steps are taken by the librarian to create awareness of the available audio-visual materials to the lecturers.

\subsection{Scope Of The Study}

The study is limited to the College of Education Katsina-Ala in Benue State but the results of the study just like any other study can be used to rectify the hindrances in colleges of education in Benue State and Nigeria at large.

The study is also limited to the use of audio-visual resources in teaching and learning processes, their effectiveness and capabilities in facilitating the flow of information between the teacher and the learners.

\subsection{Significance Of The Study}

Audio-visual materials have been in existence for a longtime, but they are often underutilized. It is expected that, following the identification of the hindrances to maximum utilization of audio-visual resources in schools, effort will be made to minimize the effect of the hindrances and promote adequate utilization of the available resources. Discoveries from the study will guide teachers, government, sponsoring bodies and donors on the purchase of not only printed materials but also non-print materials for schools and colleges. When the use of audio-visual materials is encouraged, there will definitely by a high demand for the materials and the producers will put in more efforts in the production and even come out with more methods of applying them to teaching and learning. This may tend to expose the learner more to thinking than relying on the teacher. The research will also pave the way for research into other areas of concern and interest and will give researchers insight into this topic of investigation.

\subsection{Research Questions}

1. What types and quantity of audio-visual materials are available in the college library, College of Education Katsina-Ala?

2. How often do lecturers use audio-visual materials while teaching?

3. What type of audio-visual materials do lecturers use?

4. What are the hindrances to the use of audio-visual materials in college? 
5. In the perception of lecturers, what benefits do students derive from the use of audio-visual materials?

6. What steps has the librarian taken to increase the use of audio-visual materials among teachers?

\section{The General Over-View Of Audio-Visual Materials}

Prostano and Prostano (1982) asserted that the time immemorial, audio-visual materials existed but were not incorporated into educational system". According to the authors, the advent of audio-visual materials is long but it is the use that has been limited until in the 1960s and 1970s that libraries realised the use of these materials and started incorporating them into the library collections for future use. Summer stressing on the advent of the materials stated that "before man developed speech as a means of communication, he expressed himslelf in terms of drawings, signals and symbols". The point here is that the use of audio-visual materials started as early as man's civilization begain. This is evident in their attempt to communicate ideas. Green (1965) has this to say; "in time of antiquity, man carried pictures on rocks for conveying ideas".

Ani (1990) supporting the introduction of audio-visual aids observed that as far back as the 1920s audio-visual materials came to be used in teaching in the United State of America. According to Dike (1993), the various methods of teaching informally such as observation, participation and the use of the senses are forms of audio-visual resoruces in our indigenous Nigerian Education. The child is asked to observe carefully without verbal instructions and to participate in domestic science, craft, and agriculture, the child is able to grasp knowledge from different fields unconsciously.Thus every child has the right to knowledge and information especailly that which concerns his cultural heritage". It is imperative theirefore that in cultures whose traditions are essentially of the oral rather than the writer kind, knowledge and information transfer be effected by using verbal instructions and the preservation of their cultural arts. This is the meaning of the story telling sessions in our indigenous African education.

In modern times, the value of insttuctional materials has been realised of late in this country and attempts are being made by all organs connected with education to see that audio-visual materials are used in teaching and learning situations. For examples, University of Nigeria, Nsukka has established Curriculum Development and Instructional Materials Centre (CUDIMAC) to promote the utilization of various types of audio-visual resoruces and media in the school.

In advances in librarianiship, (Hallett,T.L.andFaria,G. 2006) points out that, books are not the only way the libraries can extend the available information to the public but other means such as pictures, filmstrips, slides, recording etc. should be acquired to suppliment book resoruces and to substitute for books when they are not available on a particular topic. That is, in the modern educational methods modern technologies have given rise to various means of teaching which make it easier for both the teacher and learner to achive their aims of teaching and learning.

The Encyclopeadia of library and information science asserted that libraries serving formal education have tended over the years to broden their inventories of non book or audio-visual materials rapidly and to accept increased responsibiliteis for distribution of audio-visual equipment, e.g emotion pictures, projectors as well as establishing local duplication and production services (e.g. of overlay transporencies).

\section{Types Of Audio-Visual Materials}

There are different ways of classifying audio-visual materials. As listed by (Fayemi,T.A) together with the nessary related equipment for putting them to work in the classroom, audio-visual materials include the following:

\section{REALIA in social and physical environment}

These materials, situations, and the people have to be visisted, studied, observed, reacted to and worked with, right in their natural environment. The study of relia may then demand field trips, demonstration, experiments and other direct experiences as processes for getting the meaning. They may come into the class in display cases or attached on bulletin boards.

Dramatic performances (portrayal of people, events, procedures) dolls and puppets are produced for use as dramatic models.

Models, Mock-ups Globes, and Relief Maps. These can be purchased or produced by the teachers and students jointly. Exhibits and dioramas made up of models can be borrowed, purchased or constructed.

Television programmes: This requires television receivers and antenna systems. They can be produced jointly by students and teacher as learning experiences.

Motion pictures: Projection equipment for accommodation either optical and/or magnetic sound tracks and projection screens are required. Still pictures projection materials include transparencies and microprojector materials (microscopic slides and microscopic slides and microscopic objects).

Study prints and pictorial illustrations

Radio and Audio programmes, as found in tapes or disk recordings and radio broadcasts. 
Graphic materials such as maps, graphs, cartoons, diagrams and charts.

According to (Aina,M.E and Olutade S.A. 2006), the chief visual tools which can be used by the teacher may be classified as follows:

\section{Pictorial and Graphic Aids}

Chalkboard

Textbooks illustrations

Charts

Pictures (a) Drawing

(b) Reproductions

(c) Photographic

Maps of various types

Diagrams. Picture language (Isotype, etc)

\section{Optical Aids}

Episcope

Diacopes (a) Standard Lantern

(b) Sub-standard slide projector

(c) Strip projector

(d) Micro-slide projector

\section{6mm Cinematograph}

$\begin{array}{lll} & \text { (a) } & \text { Silent } \\ & \text { (b) } & \text { Sound } \\ \text { Specimens } & \text { (a) } & \text { Actual objects } \\ & \text { (c) } & \text { Facsimiles or reproductions }\end{array}$

Models (a) Reduced

(b) Enlarged

(c) Sectional

(d) Working, included real objects e.g. school visits

The direct experience

The contrived experience or "Mock-up"

Dike (1993) grouped audio-visual materials into:

Audio resources such as records, tapes and cassettes, and radio broadcasts.

Visual resources including models, real objects, three dimensional displays, the chalkboard, bulletin board, adhesives, graphs, diagrammes, charts, maps, cartons, posters and pictures and projected forms like transparencies, slides, filmstrips and films.

Audio-visual combinations e.g. sould film and filmstrips, slides-tape decks, television programmes, videotapes and dramatization.

Others such as educational programmes/games, programmed instructions, demonstration and field trips.

From the above we can see that $\mathrm{A} / \mathrm{V}$ resources are divided into audio visual and a combination of audio and visual resources and others which are class with audio-visual resources which can either be in a projected or non-projected forms.

\section{Description Of Sample}

The population of the study comprises all the lecturers and students in the College of Education Katsina-Ala. There are about two hundred and thirty six (236) lecturers in the school and three thousand six hundred and seventy five $(3,675)$ students for the 1998/99 academic session, excluding remedial and preliminary studies students.

\section{Sampling Method}

A total number of sixteen to twenty students are selected from each of the faculties (which are called schools in the college) in order to ensure fairness. 
Table 1:Faculties and number of respondents from students and staff

\begin{tabular}{|l|l|l|}
\hline Faculty & Staff & Students \\
\hline Faculty of Education & 17 & 20 \\
\hline Faculty of Languages & 16 & 16 \\
\hline Faculty of Social Sciences & 16 & 16 \\
\hline Faculty of Natural Sciences & 18 & 16 \\
\hline Faculty of Vocation Education & 17 & 16 \\
\hline Faculty of Arts & 16 & 16 \\
\hline Total & $\mathbf{1 0 0}$ & $\mathbf{1 0 0}$ \\
\hline
\end{tabular}

This method of sampling is called stratified random sampling. The selection was done to ensure the representation of every faculty or to proportionately represent each group in the population.

By doing this, the researcher gave more attention to the faculties than departments. In each faculty, students were randomly given the questionnaire bearing in mind the year of study of each of them so that the information collected will cut across the students of various levels in the faculty. To ensure this on the part of students and their lecturers, their year of study and rank of the lecturers, were sought to know before given the questionnaire to them.

These lecturers are made up of different designations ranging from Lecturer I, Lecturer II, Lecturer III, Assistant lecturer, Senator Lecturers, Principal Lecturer and Chief Lecturers. Some of the students are in part one, some in part two and three. Their mode of entry is either through College of Education, JAMB (Junior JAMB) or after passing their Preliminary Studies in various departments. The sample population therefore consists of such students and lecturers.

The sample population is taken from these groups because, they are the people involved with the use of audio-visual materials while teaching and learning respectively. For these reasons, they are in a better position to give the required information concerning audio-visual materials as regards their usefulness, availability, how often they are used in teaching and the level of improvisation.

\section{Instrument For Data Collection}

The instrument used for data collection in this research consisted of two sets of questionnaire for students and lecturers. The questionnaires were designed by the researcher in close consultation with her supervisor. The questions were set to match the research questions in chapter one. The questionnaires were made up of both fixed response and open - ended questions because of the nature of the study which desires to know the forms, aspects and details about the use of audio-visual resources in the college.

There were many categories of options or responses to each question in the questionnaires. These range from very often, often, sometimes, never, very adequate, fairly adequate, rarely, encouraging, fairly encouraging, not encouraging. In completing the questionnaire the questionnaire, 98 copies were returned by the teachers.

The number of questionnaire for both students and teachers were some (one hundred copies) irrespective of the differences in the population. This is because, the researcher wanted to get a meaningful number of respondents from the lecturers who are supposed to be the actual users of audio-visual aids to teach the students. The response from the students is just supplemental to those of the lecturers.

\section{Method Of Data Collection}

The researcher visited the college physically to administer her questionnaire and also to observe what audio-visual materials there are in the college. The questionnaires were given by hand to students and lecturers and collected on the sport within two days.

\section{Method Of Data Analysis}

The data collected for this research work were organized and analysed. Because the data obtained in the study are mainly descriptive, non-parametric statistical techniques such as percentage, frequencies of numbers converted into percentages, in one case mean is used as means of analysis were used in the analysis. This helped to analyse the answers to the questions in the questionnaire and draw conclusion.

\section{Data Presentation And Analysis}

\section{Personal Data}

The results of the questionnaires are analysed considering the answers of both the lecturers and students. 
Table 2: Rank of Lecturers

\begin{tabular}{|l|l|l|}
\hline No. & Rank of Lecturers & Number of respondents \\
\hline A & Reader & - \\
\hline B & Chief lecturer & 11 \\
\hline C & Principal lecturer & 16 \\
\hline D & Senior lecturer & 16 \\
\hline E & Assistant lecturer & 10 \\
\hline F & Lecturer I & 10 \\
\hline G & Lecturer II & 22 \\
\hline H & Lecturer III & 9 \\
\hline I & Others & - \\
\hline & Total & $\mathbf{9 4}$ \\
\hline
\end{tabular}

In answering the above question, eleven lecturers marked chief lecturer, sixteen principal lecturers, sixteen senior lecturers ten assistant lecturers, ten lecturers I, twenty two lecturers II, nineteen lecturers III, nothing for readers and others, bringing the number to a total of ninety - four (94).

Table 3: Teaching Subject of Lecturers

\begin{tabular}{|l|l|l|}
\hline S/No. & Teaching Subject & Number of respondents \\
\hline 1 & Educational subject & 12 \\
\hline 2 & Agricultural sciences & 4 \\
\hline 3 & Biology & 4 \\
\hline 4 & Integrated science & 7 \\
\hline 5 & Fine and Applied Arts & 5 \\
\hline 6 & Theatre Arts & 8 \\
\hline 7 & Economics & 4 \\
\hline 8 & Geography & 8 \\
\hline 9 & History & 7 \\
\hline 10 & English language & 8 \\
\hline 11 & Christian Religious Studies & 6 \\
\hline 12 & Social studies & 10 \\
\hline 13 & Political science & 8 \\
\hline 14 & General studies & 3 \\
\hline & Total & $\mathbf{9 4}$ \\
\hline
\end{tabular}

The above table shows the number of respondents and different teaching subjects who were engaged in answering the questionnaires for the research.

\section{Research Question 1}

\section{Research Questions}

How adequate is the college's collection of audio-visual materials?

Table 4: Adequacy of Audio-Visual Material

\begin{tabular}{|l|l|l|l|l|l|}
\hline \multicolumn{6}{|l|}{ Response from Lecturer } \\
\hline Response & $\begin{array}{l}\text { Very } \\
\text { adequate }\end{array}$ & $\begin{array}{l}\text { Fairly } \\
\text { adequate }\end{array}$ & Inadequate & $\begin{array}{l}\text { No } \\
\text { response }\end{array}$ & Total \\
\hline Frequency & 2 & 22 & 61 & 9 & 94 \\
\hline$\%$ & $2 \%$ & $23 \%$ & $65 \%$ & $10 \%$ & 100 \\
\hline
\end{tabular}

Table 4 shows that out of the 94 lecturers studied, $65 \%$ of them stated that the college's collection of audiovisual materials is inadequate.

The same question was given to students but in another from, - what is the quantity of audio-visual resources in your school?

Table 5: Adequacy of audio-visual materials

\begin{tabular}{|l|l|l|l|l|l|}
\hline & \multicolumn{4}{|l|}{ Response from Lecturer } \\
\hline Response & Encouraging & $\begin{array}{l}\text { Fairly } \\
\text { encouraging }\end{array}$ & $\begin{array}{l}\text { Not } \\
\text { encouraging }\end{array}$ & $\begin{array}{l}\text { No } \\
\text { response }\end{array}$ & Total \\
\hline Frequency & 10 & 44 & 34 & 10 & 98 \\
\hline$\%$ & $10 \%$ & $45 \%$ & $35 \%$ & $10 \%$ & 100 \\
\hline
\end{tabular}


From the data obtained on research question I from students, a total number of 98 students were studied and 10 percentage of the total number stated that the college's collection of audio-visual materials is encouraging, $45 \%$ said it is fairly encouraging and 35\% not encouraging, another 10\% did not respond to the question. Based on the number that responded to the question therefore, it is evident that students found the college's collection of audio-visual aids fairly adequate while the lecturers said it is inadequate.

The researcher was also there herself. Observation showed that the quantity of audio-visual materials available in the school is fairly encouraging. I discovered they have some audio-visual materials in the library which lecturers more often than not use. There is another media centre controlled by a lecturer of the educational technology, which I made effort to see and hear from him to no avail. There is also a language laboratory which is newly established for effective teaching of languages and language skills. To be specific, the library's collection of audio-visual resources is inadequate, but with what I saw in the language laboratory is impressive and same was said of the media centre.

Another question was asked on the level of improvisation of these materials in the school: which of the audio-visual materials do you improvise? Lecturers when asked the above question replied that they do improvise some of the materials at their reach, improvise as in bringing them from their homes, e.g. such materials like models, maps, magazines, newspapers, radio, specimens, posters, pictures and cassette recorders. $5 \%$ of them stated that they do improvise.

\section{Research Question 2}

How often do lecturers use audio-visual materials in teaching?

Table 6: Frequency of Use

\begin{tabular}{|l|l|l|l|l|}
\hline & \multicolumn{5}{|l|}{ Response from Lecturer } \\
\hline Response & Often & Rarely & Never & Total \\
\hline Frequency & 23 & 50 & 25 & 98 \\
\hline$\%$ & $23 \%$ & $51 \%$ & $26 \%$ & 100 \\
\hline
\end{tabular}

The table for research question 2 indicates that a good number of the teachers rarely use audio-visual resources in teaching. According to the table and the data collected, 51\% of the lecturers rarely use audio-visual materials, $26 \%$ of them don't use or have never used audio-visual materials; $23 \%$ often use audio-visual resources. Therefore, it is concluded that the lecturers in the college RARELY use audio-visual resources in teaching.

\section{Research Questions 3}

What types of audio-visual materials do lecturers use? Lecturers were asked how often they use the following $\mathrm{A} / \mathrm{V}$ materials in teaching. In the analysis of this question, because of the number of items, mean has been chosen to explain the figures. The various alternatives for the question are:

$\begin{array}{llll}\text { Very often } & = & \mathrm{VO} & \text { the alternatives were ranked in this } \\ \text { Often } & = & \mathrm{O} & \text { order } 4,3,2,1 \\ \text { Sometimes } & = & \mathrm{S} & \\ \text { Never }= & \mathrm{N} & & \end{array}$

Table 7:Frequency of Use

\begin{tabular}{|l|l|l|l|l|l|l|l|}
\hline & Responses from lecturer & VO & $\mathrm{O}$ & $\mathrm{S}$ & $\mathrm{N}$ & $\underline{\mathrm{X}}$ & Decision \\
\hline S/No. & Items & 23 & 12 & 35 & 24 & 2.4 & $\mathrm{~S}$ \\
\hline 1 & Posters & 25 & 16 & 36 & 17 & 2.5 & VO \\
\hline 2 & Pictures/photographs & 72 & 6 & 8 & 8 & 3.5 & $\mathrm{~N}$ \\
\hline 3 & Chalkboard & 4 & 3 & 25 & 62 & 1.6 & $\mathrm{~N}$ \\
\hline 4 & Cassette recorders & 4 & - & 8 & 82 & 1.2 & $\mathrm{~N}$ \\
\hline 5 & Disc & 4 & 5 & 10 & 75 & 1.3 & $\mathrm{O}$ \\
\hline 6 & Magnetic boards & 40 & 20 & 20 & 14 & 2.9 & $\mathrm{O}$ \\
\hline 7 & Magazines/Newspapers & 26 & 24 & 18 & 28 & 2.5 & $\mathrm{~S}$ \\
\hline 8 & Maps & 27 & 12 & 15 & 40 & 2.4 & $\mathrm{~N}$ \\
\hline 9 & Models & - & 20 & 20 & 54 & 1.6 & $\mathrm{~N}$ \\
\hline 10 & Flannel boards & 21 & 4 & 19 & 50 & 2.1 & $\mathrm{~N}$ \\
\hline 11 & Radio & 2 & - & 18 & 74 & 2.0 & $\mathrm{~N}$ \\
\hline 12 & Slides & 2 & 12 & 8 & 72 & 1.4 & $\mathrm{~N}$ \\
\hline 13 & Sound projectors & 3 & 17 & 7 & 67 & 1.4 & $\mathrm{~N}$ \\
\hline 14 & Computer & 2 & 9 & 18 & 65 & 1.5 & $\mathrm{~N}$ \\
\hline 15 & Television & 12 & 21 & 20 & 41 & 2.0 & $\mathrm{~S}$ \\
\hline 16 & Field trips & 27 & 14 & 2 & 51 & 2.2 & $\mathrm{~S}$ \\
\hline 17 & Specimens & & & & & \\
\hline
\end{tabular}


According to the data collected and analysed, the result from the responses obtained from lectures shows that chalkboard is the only $\mathrm{A} / \mathrm{V}$ material that is very often used. Three other materials, maps, magazines/newspapers cut out, pictures/photographs are often used, the rest are either used sometimes or never which falls below the criteria mean of 2.5 indicating that $\mathrm{A} / \mathrm{V}$ materials are not often used in the college. It is not surprising because, chalkboard is the most fundamental teaching aid which no institution could afford not to use or have.

\section{Research Question 3}

Table 8:Frequency of Use

\begin{tabular}{|l|l|l|l|l|l|l|l|}
\hline & Responses from students & $\mathrm{VO}$ & $\mathrm{O}$ & $\mathrm{S}$ & $\mathrm{N}$ & $\underline{\mathrm{X}}$ & Decision \\
\hline S/No. & Items & 30 & 26 & 36 & 6 & 2.8 & $\mathrm{O}$ \\
\hline 1 & Posters & 31 & 20 & 35 & 12 & 2.7 & $\mathrm{O}$ \\
\hline 2 & Pictures/photographs & 85 & 8 & 5 & - & 3.8 & VO \\
\hline 3 & Chalkboard & 9 & 16 & 16 & 57 & 1.8 & $\mathrm{~N}$ \\
\hline 4 & Cassette recorders & - & 8 & 10 & 80 & 1.3 & $\mathrm{~N}$ \\
\hline 5 & Disc & 4 & 1 & 22 & 71 & 1.4 & $\mathrm{~N}$ \\
\hline 6 & Magnetic boards & 32 & 28 & 24 & 14 & 2.8 & $\mathrm{O}$ \\
\hline 7 & Magazines/Newspapers & 45 & 20 & 18 & 15 & 3.0 & VO \\
\hline 8 & Maps & 40 & 20 & 17 & 21 & 2.8 & $\mathrm{O}$ \\
\hline 9 & Models & - & 8 & 20 & 70 & 1.4 & $\mathrm{~N}$ \\
\hline 10 & Flannel boards & 8 & 10 & 15 & 65 & 1.6 & $\mathrm{~N}$ \\
\hline 11 & Radio & 8 & - & 15 & 75 & 1.4 & $\mathrm{~N}$ \\
\hline 12 & Slides & 4 & 4 & 20 & 70 & 1.4 & $\mathrm{~N}$ \\
\hline 13 & Sound projectors & 4 & - & 20 & 74 & 1.3 & $\mathrm{~N}$ \\
\hline 14 & Filmstrips & 47 & 19 & 12 & 20 & 2.9 & $\mathrm{OF}$ \\
\hline 15 & Specimens & 2 & 6 & 16 & 74 & 1.3 & $\mathrm{~N}$ \\
\hline 16 & Television & 2 & 6 & 10 & 80 & 1.3 & $\mathrm{~N}$ \\
\hline 17 & Computer & 30 & 16 & 29 & 23 & 2.5 & $\mathrm{O}$ \\
\hline 18 & Field strips & & & & & \\
\hline
\end{tabular}

The table above giving responses of students is showing different kinds of $\mathrm{A} / \mathrm{V}$ materials and the response of their utilization presented in mean (X). It shows that only maps and chalkboards are very often used by teachers in teaching. The rest are either often used or not used at all but the number of those not used surpasses that number of often used.

\section{Research Question 4}

What are the hindrances to the use of audio-visual materials in the colleges?

The different factors given by the lecturers and students are grouped under three broad headings for easy discussion and analysis.

Table 9:Hindrances to Use

\begin{tabular}{|l|l|l|}
\hline Available Factors & Frequency & $\%$ \\
\hline Non-availability & 44 & 22.9 \\
\hline Financial constraints & 40 & 20.8 \\
\hline Removal by staff/students & 18 & 9.4 \\
\hline Inadequate & 14 & 7.3 \\
\hline Non-replacement & 6 & 3.1 \\
\hline Supporting Factors & & \\
\hline Maintenance & 42 & 21.2 \\
\hline No spare parts & 12 & 6.3 \\
\hline No storage facilities & 14 & 7.3 \\
\hline Unstable power supply & 18 & 9.4 \\
\hline Lack of operating materials & 6 & 3.1 \\
\hline Human Factors & & \\
\hline Lack of manpower & 58 & 30.2 \\
\hline No commitment by teachers & 8 & 4.2 \\
\hline Lack of time & 10 & 5.2 \\
\hline Laziness & 18 & 9.4 \\
\hline Lack of awareness of their importance & 10 & 5.2 \\
\hline Students attitudes towards learning & 4 & 2.1 \\
\hline
\end{tabular}

Percentages were based on number.

The percentages are based on the total number of respondents from students and lecturers. The three tables are showing various factors that are responsible for the use of audio-visual materials in the College of Education Katsina-Ala. 
It can be observed that under the three main factors under which some of the factors fall, the percentages are very, very, low meaning that availability, supporting infrastructures and human factors are actually the hindrances to the use of $\mathrm{A} / \mathrm{V}$ resources in that school. The percentages deviate so much from normal.

\section{Research Question 5}

What benefit do students derive from the use of $\mathrm{A} / \mathrm{V}$ materials?

The responses given by the lecturers shows that there are a number of benefits that students derive from the use of audio-visual materials. The responses are represented on the table below:

\section{Table 10: Benefits of use}

\begin{tabular}{|l|l|l|l|}
\hline S/No. & & Frequency & $\%$ \\
\hline 1 & Quick understanding & 121 & 63.0 \\
\hline 2 & Makes lesson realistic & 32 & 16.6 \\
\hline 3 & Students are happy & 16 & 8.3 \\
\hline 4 & Students are interested & 17 & 8.9 \\
\hline 5 & Students are motivated & 23 & 11.9 \\
\hline 6 & Encourages participation & 10 & 5.2 \\
\hline 7 & Serves as reference materials & 23 & 11.9 \\
\hline 8 & Makes learning permanent & 55 & 28.7 \\
\hline 9 & It saves time & 33 & 17.2 \\
\hline 10 & Makes learning easier & 65 & 33.9 \\
\hline 11 & Fosters explanations & 61 & 31.8 \\
\hline 12 & Gives experience & 28 & 14.6 \\
\hline 13 & Students learn to operate them & 18 & 9.4 \\
\hline 14 & Confident of what is taught & 4 & 2.0 \\
\hline
\end{tabular}

Percentage based on numbers

The table above shows responses from students and lecturers on the benefits that students derive from the use of $\mathrm{A} / \mathrm{V}$ materials. The table is presented in frequencies and percentages. The percentages are based on the total number of responses from students and lecturers. The outstanding benefit as shown by the table is quick understanding, which has $63 \%$. This is to tell us that although numerous benefits are derived from A/V materials quick understanding weighs more.

\section{Research Question 7}

What steps has the librarian taken to increase the use of audio-visual materials among lecturers?

Lecturers were asked if they were given any information on available audio-visual materials in the library by the librarian.

Table 11: Information given by Librarian

\begin{tabular}{|l|l|l|l|}
\hline Response & Yes & No & Total \\
\hline Frequency & 30 & 64 & 98 \\
\hline$\%$ & 32 & 68 & 100 \\
\hline
\end{tabular}

From the above table, it is observed that the amount of awareness created by the audio-visual librarian is not impressive: $68 \%$ of the population stated that no information is given them as per the availability of instructional materials while $32 \%$ agree that they are made aware of the available materials in the library by the librarian.

\section{Interpretation Of Data}

In this chapter, the results of the investigation which were fully analysed in chapter four shall be discussed. Conclusions are drawn, implication of the study for educational purposes and suggestions for further research are pointed out.

\section{Discussion Of Results \\ Research question 1}

How adequate is the college's collection of audio-visual materials?

Table 3 and 4 show the results of the above question. Table 3 contains responses from lecturers and it shows that the college's collection of audio-visual materials is in adequate as it is reflected a $65 \%$ of the total population. While table 4, response from students shows states that collection of $\mathrm{A} / \mathrm{V}$ materials in the college is fairly encouraging. This is represented by $45 \%$ of the population. There is a contradiction between inadequate and fairly encouraging but this should mark a limitation to the study. However, the researcher's observation is that the college's collection of A/V materials is fairly encouraging. This is because, although the collection of these resources in the library is very poor, there are two other centres in the college that supplement the library's 
collections of $\mathrm{A} / \mathrm{V}$ materials. These are the language laboratory and the media centre respectively. They are equipped to a high standard and since our question is based on the college in general, it is found worth-wile to conclude that the $\mathrm{A} / \mathrm{V}$ collection in the college is fairly encouraging.

\section{Research Question 2}

How often do your lecturers use audio-visual resources in teaching?

Table 6 answered this question by showing that the lecturers' use of audio-visual materials is not excellent. The table indicates that $23 \%$ of the lecturers often use audio-visual resources while $51 \%$ rarely use and $26 \%$ had never used them at all.

\section{Research question 3}

How often do you use the following A/V materials?

Table 7 and 8 presented data on the utilization of some particular types of audio-visual materials in the college. There were 18 items on tables. The instrument for data analysis of this particular research question was mean $(\underline{X})$ and the criteria mean was 2.5 . That is any item that falls short of the criteria mean has a negative response to the question. Therefore, table 7 which is responses from lectures shows that only four items have positive response for the questions. These are items 2 , often, item 3 very often, item 7 often and item 8 often.

Table 8 responses from students showed that 8 items have a positive response for the research question. Item 3 and 8 showed very often while 1, 2, 7, 9, 15, 18 showed often. This therefore tells us that although the college's collection of $\mathrm{A} / \mathrm{V}$ materials is fairly adequate, there is very low utilization rate.

\section{Research question 4}

What are the hindrances to the use of audio-visual materials in the college?

The responses for this research question were derived from both students and lecturers. The frequencies for each factor was put together to arrive at one number from both respondents. Table 9 presented data on the hindrances to the use of $\mathrm{A} / \mathrm{V}$ resources in the form of frequencies and percentages. The percentages are very low. They deviated so much from an average of $100 \%$. This is to tell us that the hindrances put in table 9 nonavailability of $\mathrm{A} / \mathrm{V}$ resources, supporting infrastructures and human factors are highly responsible for the nonuse of audio-visual resources in the college.

\section{Research question 5}

What benefits do you think students derive from the use of $\mathrm{A} / \mathrm{V}$ materials?

Table 10 presented the data on the benefits students derive from the use of audio-visual materials in frequencies and percentages for respondents from students and lecturers. The table, presented 14 different benefits that students derive. However, quick understanding stood as an outstanding benefit among them all. Quick understanding carried 63\% of the response while the other factors were below the average of 100 percent.

\section{Research question 6}

Are you given information on available audio-visual materials in the library by the librarian?

Table 11 has the information of the awareness of available audio-visual material in the library. The responses showed that the awareness created by the librarian is not impressive. The data showed that $68 \%$ of the populations are not given any awareness of the available audio-visual materials.

\section{Conclusion} been drawn:

From the observation, and the result obtained after the investigation, the following conclusions have There are inadequate teaching aids in the College of Education, Katsina-Ala.

The available ones are not effectively exploited by both students and staff.

Obsolete $\mathrm{A} / \mathrm{V}$ resources in the school are not replaced.

Human factors or lack of manpower to man the available $\mathrm{A} / \mathrm{V}$ resources is the greatest hindrances of the use of $\mathrm{A} / \mathrm{V}$ resources in the school.

A good number of lecturers do not use $\mathrm{A} / \mathrm{V}$ aids in teaching.

There are future plans for the development of $\mathrm{A} / \mathrm{V}$ materials in the college.

This is evident is the media centre and language laboratory newly established. The language laboratory is well equipped and the same thing/impression is given of the media centre, although I could not go in to observe the level of the resources. The master in charge was not around. 
I will recommend that:

\section{Recommendations}

1. Curriculum planners should encourage the use of audio-visual materials by inculcating them in the educational syllabus of all levels of education.

2. That states school management boards should pave way for efficient funding for libraries and audio-visual resources in school.

3. Students and teachers alike should get involved in their various roles in the improvisation and utilization of audio-visual resources when necessary.

Libraries within Katsina-Ala or Benue State should engage in inter-library loan where one member library can borrow from the other, audio-visual aids she doesn't have for use within an accepted period of time.

The audio-visual librarian should improve in making known to the lecturers the available audio-visual resources in the library at any moment in time.

\section{SUMMARY OF THE STUDY}

The study was aimed at finding out the use of audio-visual materials in the teaching and learning processes in colleges of education, and the College of Education Katsina - Ala in particular.

To make this possible, 13 questions were framed to bring out the desired answers to the research questions. There were six research questions and two sets of questionnaires were administered to students and lecturers in order to elucidate the needed information. Percentages and frequencies of the results were worked out and mean $(\underline{X})$ was used on research question three because of the ambiguity of the question. From the results obtained, it was found that:

The college's collection of audio-visual materials is fairly adequate.

The lecturers in the college RARELY use audio-visual resources in teaching.

The chalkboard is the only audio-visual aid that is often used by the lecturers.

Availability, lack of supporting infrastructures, and human factors are the limiting factors to the use of audio-visual materials in the college.

There are numerous benefits that students derive from the use of audio-visual aids, but quick understanding weighed more.

1. The awareness of available $\mathrm{A} / \mathrm{V}$ resources created by the librarian is not impressive, and that a good number of the lecturers improvise some of the material when necessary.

\section{References}

[1]. Aina, M.E and Olutade, S.A (2006). General Teaching Methods:nSchool of Education National Open University, Nigeria.

[2]. Anzaku Francis (2011). Library Experts Speaks on Audio-Visual Material. A paper presented at the United Nations Educational, Scientific and Cultured Organization (UNESCO) World Day for Audio-Visual Heritage. Lafia.

[3]. Anueleonue, N.C. (2008) Using Information Communication Technology (ICT) in Secondary Schools: Prospects and Challenges for $21^{\text {st }}$ Century. Multidisciplinary Journal of Research Development. National Association for Research Devloptment (NARD) 10(1) 178-182 July.

[4]. Dike, V.W (1993). Library Resources in Education, Enugu: ABIC Publisher

[5]. Eze, E.U. (2005). Effect of Instructional Materials on the Acadmic Performance of Junior Secondary School Students in Social Studies. Unpublished PGDE Thesis. Imo State University-Nigeria

[6]. Fayemi T.A (1991). The Effect of Instructional Materials on Learning of History in Selected Primary Schools in Ogbomosho Local Government Area: Unpublished B.ED Thesis.

[7]. Federal Republic of Nigeria (2008), National Policy on Education. Revises Federal Government Press.

[8]. Gopal Vinayak Patil. (2010). Importance of Audio-Visual in teaching methodology. Mahourastra, India.

[9]. International Federation of Library Associations and Institutions IFLA, (2004). Guidelines for Audio-Visual and Multimedia Materials in Libraries and other Institutions archive.infla.org/vll/535/pubs/avm-guidelines04.htm.

[10]. Hallett, T.L and Faria, G (2006), Teaching with Multimedia: Do Bells and Wishtles Help Students Learn . Journal of Technology and Human Services 24(2/3): 167-79

[11]. Katherine Martin (2009) Audio-Visual Materials: Collection Development Policy, Rod Library University of Northern lowa.

[12]. Lestage. Andre (1959). The use of Audio-Visual Aids in Education: Extracted from UNESCO Chronicles, Regional Seminar on the use of Audio-Visual Aids in Adult and School Education in Latin America at Mexico City from 28 September to 17 October 1959.

[13]. Mcnaught, A (2007), Moving Images and Sound : Inclusive and Accessible. Moving Images Knowledge and access: The BUFVC Handbook edited by C. Grant and I. Mekere London: British Universities Film and Video Council pp. 29-33.

[14]. Natoli, Carol (2011). The Importance of Audio-Visual Materials in Teaching and Learning. wwwhelium.com/channels/224-earlychildhood-ed.

[15]. Ngozi, B.O, Samuel A.O, Ameh O.I, (2012), Motivating use of Audio-Visual in a Nigeria Technological University Library. Journal of Edcation and Social Research Vol. 2(1) Jan.

[16]. Oketunji I (2000), Application for Information Technologies in Nigerian Libraries: Probles and Prospects in I.K : Nwalo (ed); Information Technology in Library and Information Technology Education in Nigeria. National Association of Library and Information Sceience Education NALISE

[17]. Prostano and Prostano (1982), The School Library Medis Centre $3^{\text {rd }}$ USA.

[18]. Swank, R.C (2011), The Educational Function http://www.ideals.illinois.edu/bitestream/handle/2142/5455/librarytrend

[19]. Webster's Encyclopedia Unabridged Dictionary of the English Language (1994) Newyork: Gramery Books 